(c) American Dairy Science Association, 2006.

\title{
Use of Chitosan for Selective Removal of $\beta$-Lactoglobulin from Whey
}

\author{
E. Casal, A. Montilla, F. J. Moreno, ${ }^{1}$ A. Olano, and N. Corzo \\ Instituto de Fermentaciones Industriales (C.S.I.C.), C/ Juan de la Cierva 3, 28006 Madrid, Spain
}

\begin{abstract}
A method is described for selective removal of undenatured $\beta$-lactoglobulin from cheese whey based on interactions between whey proteins and chitosan. Whey was previously clarified at $\mathrm{pH} 4.5$ with addition of chitosan $(25 \mathrm{mg} / 100 \mathrm{~mL})$, and selective removal of $\beta$-lactoglobulin was studied in the $\mathrm{pH}$ interval 4.6 to 6.5. Addition of chitosan caused selective precipitation of $\beta$-lactoglobulin that increased with $\mathrm{pH}$. The content of $\beta$ lactoglobulin in whey decreased as the amount of chitosan added was increased. At $\mathrm{pH}$ 6.2, addition of 1.9 to $3.0 \mathrm{mg} / \mathrm{mL}$ of chitosan led to complete removal of $\beta$ lactoglobulin, whereas at least $80 \%$ of the rest of whey proteins remained in solution. The production of cheese whey without $\beta$-lactoglobulin could help to expand the applications of dairy by-products in food processing, and to isolate hypoallergenic whey protein concentrates.
\end{abstract}

Key words: chitosan, $\beta$-lactoglobulin, cheese whey fractionation

\section{INTRODUCTION}

Whey, the main by-product generated during cheese and caseinate manufacture, contains about $55 \%$ of the milk nutrients including soluble salts, lactose, and water-soluble proteins. The use of microfiltration and ultrafiltration/diafiltration for removing lactose and salts has enabled the industry to manufacture whey protein concentrate (WPC), which has many uses in the food industry (Neall, 2002). The heterogeneous nature of WPC preparations is typical of many commercial products and the observed functionality is the sum of the functionality of individual proteins (Alomirah and Alli, 2004). The development of new processes for the recovery of protein from whey has resulted in a considerable increase in the number of whey protein products available, increasing their applications as food ingredients.

Whey contains a heterogeneous mixture of proteins with a wide range of functional properties with applica-

Received December 2, 2005.

Accepted December 15, 2005

${ }^{1}$ Corresponding author: j.moreno@ifi.csic.es tions for not only the food industry but also for the chemical, pharmaceutical, and cosmetic industries. The main whey protein fraction consists of a mixture of $\beta$ LG, $\alpha$-LA, immunoglobulins, serum albumin, and lactoferrin. The development of new processes for the isolation of individual whey protein species with constant and well-defined properties allows novel and expanded uses of whey. For instance, the principal protein constituent of human milk is $\alpha$-LA, which represents approximately $30 \%$ of the total protein in this milk. Moreover, human milk contains negligible quantities of $\beta$-LG. Under these circumstances, removal of $\beta$-LG from cheese whey would find immediate application as the primary protein constituent of infant formulas with a protein composition more similar to that of human milk (Heine et al., 1991; Pearce, 1991; Bramaud et al., 1997).

On the other hand, the $\beta$-LG fraction has excellent functional properties such as gelation and foaming (Zayas, 1997) and has potential applications in manufactured food products.

Several procedures have been proposed for separation of individual whey proteins including salting-out (Mailliart and Ribadeau-Dumas, 1988), selective precipitation (Hidalgo and Hansen, 1971), chromatographic techniques (Armstrong et al., 1970; Sienkiewicz, 1975; Schnack et al., 1978; Haeusel et al., 1990; Outinen et al., 1996; Felipe and Law, 1997; Gurgel et al., 2000; Leman and Dolgan, 2001), and membrane filtration (Kinekawa and Kitabatake, 1996; Cheang and Zydney, 2003). These processes have not been widely implemented for large-scale purification because of their complexity, high cost, low overall yield, poor selectivity, and unacceptable product degradation associated with the extremes of heat, $\mathrm{pH}$, or salt used during the process (Zydney, 1998; Cheang and Zydney, 2003).

Chitosan, a polysaccharide comprising copolymers of glucosamine and $\mathrm{N}$-acetyl-glucosamine has great potential in food industry and biotechnology applications because of its unique cationic character (Chavasit et al., 1988). Being a nontoxic, biocompatible, and biodegradable polymer, chitosan can be used safely by the dairy processing industry (Muzzarelli et al., 1997; Mukhopadhyay et al., 2003). Chitosan has been shown to be an effective coagulating agent in wastewater treatment and recovery of lipids and proteins from plant processing food wastes (Knorr, 1991; Jun et al., 1994; Fer- 
nández and Fox, 1997) including dairy wastewater (Selmer Olsen et al., 1996), as well as in precipitation of casein micelles (Ausar et al., 2001). In the dairy industry, chitosan has been used to remove milk fat, proteins, and peptides from cheese whey (Bough and Landes, 1976; Kennedy et al., 1992; Hwang and Damodaran, 1995; Fernández and Fox, 1997; Mukhopadhyay et al., 2003); however, no selective recovery of individual whey proteins has been achieved using chitosan. Whey proteins show different structures and physical and chemical properties and, therefore, chitosan should be an efficient selective coagulant for individual whey proteins under adequate conditions.

The aim of this work was to find fractionation conditions suitable for selective removal of $\beta$-LG from whey using chitosan as a coagulant.

\section{MATERIALS AND METHODS}

\section{Chemicals}

Low-molecular-weight chitosan (average molecular weight $=120 \mathrm{kDa}$ ) with $85 \%$ deacetylation was supplied by Aldrich (Milwaukee, WI). Rennet powder was obtained from Hansen's Laboratorium (Copenhagen, Denmark) and starter culture Lactococcus lactis ssp. lactis and Lc. lactis ssp. cremoris MA0 11 from EZAL (Rhodia Iberia, Spain).

\section{Rennet Whey Preparation}

Pasteurized skimmed cow's milk inoculated with $2 \%$ of starter culture was warmed to $35^{\circ} \mathrm{C}$. When the $\mathrm{pH}$ reached $6.3, \mathrm{CaCl}_{2}(0.25 \mathrm{~g} / \mathrm{L})$ and rennet powder $(0.1 \mathrm{~g} /$ L) were added. After coagulation, the curd was cut to the adequate grain size (approximately a rice grain), and the mixture of curd particles and whey was gently stirred and heated to $45^{\circ} \mathrm{C}$ to reduce the moisture content in the curd. Finally, the whey was filtered through glass wool.

\section{Clarified Whey}

Precipitation of lipids and suspended solids by chitosan was as follows: different aliquots of $1 \%$ (wt/vol) chitosan in $10 \%$ acetic acid were added to cheese whey to obtain solutions of $0.2,0.25$, and $0.3 \mathrm{mg}$ of chitosan/ $\mathrm{mL}$. The $\mathrm{pH}$ was adjusted to 4.5 and the mixture was vigorously stirred for $1 \mathrm{~min}$ to reach a complete interaction and coagulation. Then, the different samples were allowed to stand for 10,20 , and $30 \mathrm{~min}$, and centrifuged at $5,000 \times g$ for $10 \mathrm{~min}$ to separate the pellets from supernatants. Reduction of turbidity of whey was monitored by measuring the optical density at $660 \mathrm{~nm}$ (DU70 spectrophotometer, Beckman, Fullerton, CA). A con- trol, containing no added chitosan, was performed under identical conditions.

\section{Recovery of $\beta-L G$}

Clarified whey, obtained after treatment with 0.25 $\mathrm{mg}$ of chitosan/mL at $\mathrm{pH} 4.5$, was subjected to treatments with different amounts of $1 \%$ (wt/vol) chitosan in $0.1 \mathrm{M}$ acetic acid under different $\mathrm{pH}$ conditions. Chitosan $(0.18$ to $4 \mathrm{mg} / \mathrm{mL})$ was added to clarified whey and the $\mathrm{pH}$ was adjusted within the range of 4.6 to 6.5 with $1 M \mathrm{NaOH}$. The mixtures were vigorously stirred for $1 \mathrm{~min}$ to reach complete interaction and coagulation, allowed to stand for 10 to $30 \mathrm{~min}$, and centrifuged at $5,000 \times g$ for $10 \mathrm{~min}$ to separate the pellets from supernatants.

A second treatment with chitosan $(1.4 \mathrm{mg} / \mathrm{mL})$ was performed on the supernatant obtained during the first precipitation ( $\mathrm{pH} 6.2,1.4 \mathrm{mg}$ of chitosan $/ \mathrm{mL}$ ) following the conditions described above.

\section{Analytical Methods}

Reverse-Phase HPLC. Analyses of protein in solution before and after treatment with chitosan were carried out by reverse phase HPLC (RP-HPLC) using a C4 Jupiter column $(300 \AA, 250 \times 4.6$ mm i.d., $5 \mu \mathrm{m}$ particle size; Phenomenex, Cheshire, UK). Operating conditions were as follows: flow rate, $1 \mathrm{~mL} / \mathrm{min}$; solvent $\mathrm{A}, 0.1 \%$ (wt/vol) trifluoroacetic acid in double-distilled water; solvent B, $0.085 \%$ (wt/vol) trifluoroacetic acid in double-distilled water:HPLC-grade acetonitrile (10:90, $\mathrm{vol} / \mathrm{vol}$; Labscan Ltd., Dublin, Ireland). The column was equilibrated with $20 \%$ solvent $\mathrm{B}$. The elution was performed as follows: 0 to $60.0 \mathrm{~min}$, a linear gradient by increasing the concentration of solvent $B$ from 20 to $50 \%$; 60.0 to $65.0 \mathrm{~min}, 50 \%$ solvent $\mathrm{B}$ in isocratic mode; 65.0 to $65.5 \mathrm{~min}, 50$ to $100 \%$ solvent B; 65.5 to 71.0 min, $100 \%$ solvent $\mathrm{B}$ in isocratic mode. Absorbance was recorded at $214 \mathrm{~nm}$ using a Beckman $166 \mathrm{UV}$ detector (Beckman Instruments). Contents of protein in chitosan-treated solutions were expressed as a percentage of initial content. All treatments were replicated 4 times. The identity of whey proteins was confirmed by comparison of their retention times with those of the protein standards purchased from Sigma (St. Louis, $\mathrm{MO})$.

\section{SDS-PAGE}

Samples for SDS-PAGE were prepared by heating $\left(100^{\circ} \mathrm{C}\right.$, for $\left.10 \mathrm{~min}\right)$ whey with $10 \mathrm{~m} M$ Tris-HCl buffer, $\mathrm{pH}$ 8.0, containing 2.5\% SDS, $10 \mathrm{mM}$ EDTA, and 5\% $\beta$-mercaptoethanol. The SDS-PAGE was conducted 
Table 1. Turbidity change (optical density at $660 \mathrm{~nm}$ ) of whey treated (10 min) with various amounts of chitosan ${ }^{1}$

\begin{tabular}{ll}
\hline $\begin{array}{l}\text { Chitosan concentration } \\
(\mathrm{mg} / 100 \mathrm{~mL} \text { of whey) }\end{array}$ & $\begin{array}{l}\text { Optical density } \\
(660 \mathrm{~nm})\end{array}$ \\
\hline 0 & 0.269 \\
20 & 0.013 \\
25 & 0.008 \\
30 & 0.008 \\
\hline
\end{tabular}

${ }^{1}$ Results are average of 3 experiments.

with the Phast-System Electrophoresis apparatus, precast PhastGels Homogeneous 20\%, and PhastGel SDS buffer strips (Pharmacia, Uppsala, Sweden). Electrophoresis and silver staining were performed following the procedures of the manufacturer. Protein standards ( $\beta$-LG, $\alpha$-LA, immunoglobulin $\mathrm{G}$, serum albumin, and lactoferrin) were purchased from Sigma.

\section{RESULTS AND DISCUSSION}

A pretreatment of whey at $\mathrm{pH} 4.5$ with chitosan was performed to reduce turbidity before selective recovery of $\beta$-LG. The turbidity of raw whey is mainly due to the presence of lipids derived from milk fat globule membrane fragments, which remain dispersed in stable colloidal form due to their high negative charge. The mixture of whey and chitosan was incubated for 10, 20, and $30 \mathrm{~min}$. Maximum turbidity reduction was achieved after $10 \mathrm{~min}$ of incubation and did not increase with longer periods of incubation. Table 1 shows the reduction of turbidity followed by measuring optical density at $660 \mathrm{~nm}$. Addition of $20 \mathrm{mg}$ chitosan/100 mL of whey removed more than $95 \%$ of the initial turbidity from whey.

The supernatant obtained after precipitation was analyzed by RP-HPLC to determine whether loss of whey proteins occurred during treatment with chitosan at $\mathrm{pH}$ 4.5. The chromatographic profile of clarified whey was compared with untreated whey and was found to be identical, indicating that the major whey proteins remain in whey after clarification. The absence of proteins in the precipitate was confirmed by SDS-PAGE, whereas untreated whey and supernatant obtained after treatment with chitosans $(0.25 \mathrm{mg} / \mathrm{mL})$ had similar protein profiles (results not shown). Because the major whey proteins are either positively charged or electrically neutral at $\mathrm{pH} 4.5$, they did not interact with the positively charged chitosan. These results are in agreement with previous studies (Der Chyan and Srinivasan, 1995).

The effect of treatment of previously clarified whey with chitosan $(1.05 \mathrm{mg} / \mathrm{mL})$ at different $\mathrm{pH}$ values is

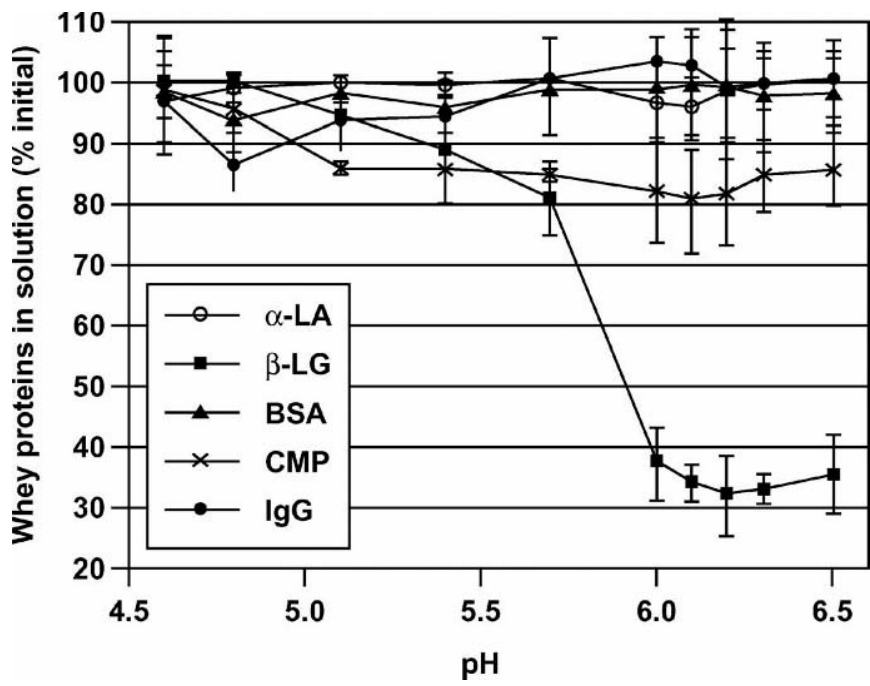

Figure 1. Effect of $\mathrm{pH}$ on the precipitation of proteins from clarified whey by addition of chitosan $(1.05 \mathrm{mg} / \mathrm{mL})$; CMP = caseinomacropeptide. Vertical bars represent standard deviation values $(n=4)$. Whey proteins were analyzed by reverse-phase HPLC following the method described in Materials and Methods.

shown in Figure 1. In a pH range of 4.6 to 5.1, the contents of $\beta-\mathrm{LG}$ and the other whey proteins remained unaltered. The $\mathrm{pH}$ range of 5.4 to 6.5 is above the isoelectric point of the main whey proteins and, therefore, all these negatively charged proteins should be susceptible to forming complexes with the positively charged chitosan. Nevertheless, only precipitation of $\beta$-LG, which increased considerably from $\mathrm{pH} 5.7$ to 6.2 , was observed. A recently published study in aqueous model solutions (Guzey and McClements, 2006) showed a strong electrostatic interaction at $\mathrm{pH} 6$ between the negatively charged groups of $\beta$-LG and the positively charged groups of chitosan.

Previous studies on polyanions complexing with whey proteins indicated that, unlike $\beta$-LG, most of the positively charged groups of $\alpha$-LA were part of large charge patches. Furthermore, $\alpha$-LA was found to have one particularly large charge patch, consisting of a cluster of 6 positively charged groups (De Vries, 2004). The presence of large positively charged patch may give rise to a strong electrostatic repulsion between $\alpha$-LA and polycationic chitosan. Although not only electrostatic forces contribute to the observed complexation behavior, the differences in the distribution of charge patches over the surfaces of both proteins may play an important role in the observed interaction between chitosan and whey proteins.

Around 10 to $20 \%$ of caseinomacropeptide was precipitated in the studied $\mathrm{pH}$ range probably because of its acid isoelectric point (pI) and the presence of sialic acid, 

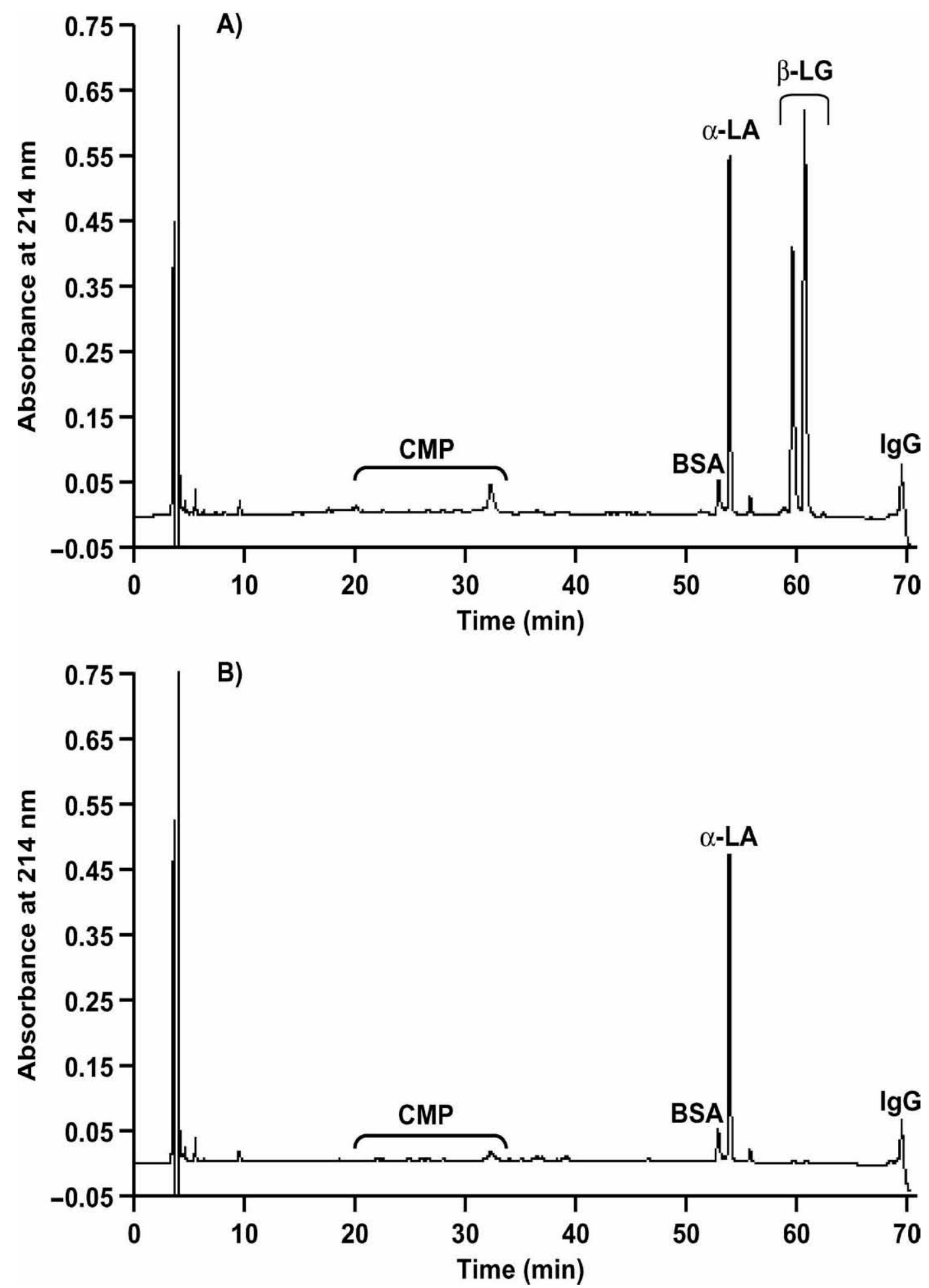

Figure 2. Reverse-phase HPLC chromatograms of A) untreated, and B) treated whey with chitosans (1.9 mg/mL) at pH 6.2.

which provides negative charge to the peptide, contributing to the formation of complexes with chitosan (Casal et al., 2005).
A second treatment with chitosan was carried out using the supernatant obtained from the first precipitation with chitosan to assess the subsequent removal of 


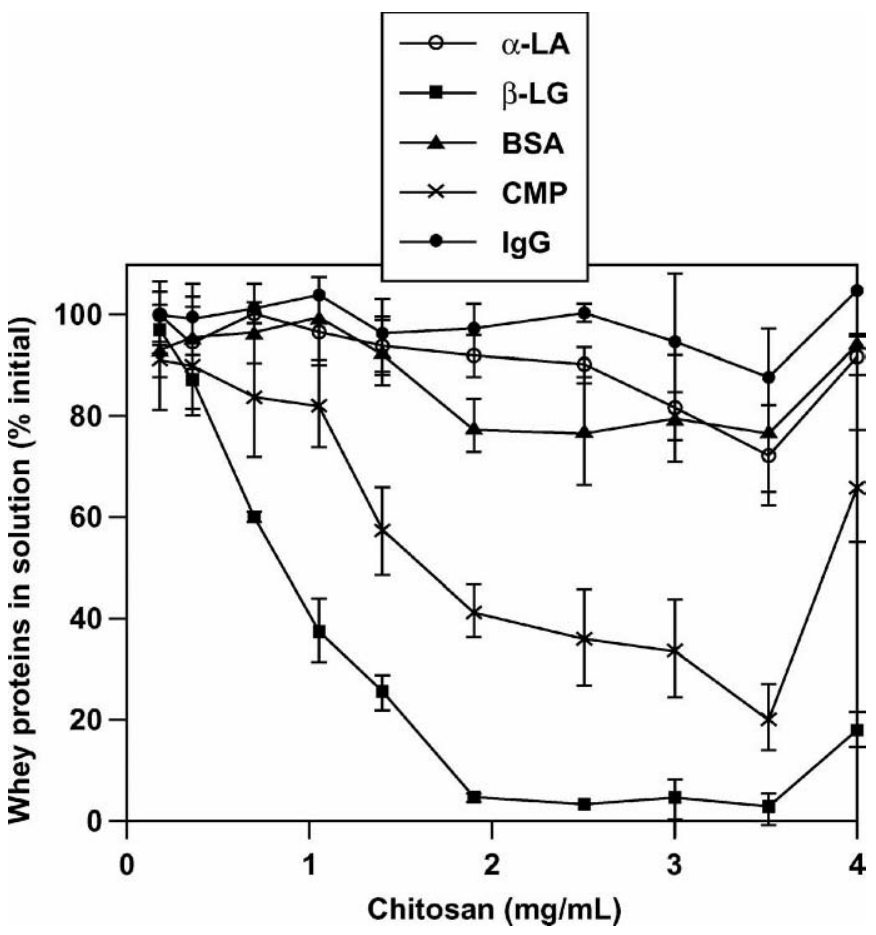

Figure 3. Effect of the amount of chitosan added to whey on the precipitation of proteins at $\mathrm{pH} 6.2 ; \mathrm{CMP}=$ caseinomacropeptide. Vertical bars represent standard deviation values $(n=4)$. Whey proteins were analyzed by reverse-phase HPLC following the method described in Materials and Methods.

other whey proteins. No additional precipitation was obtained in the studied $\mathrm{pH}$ range and only remnants of $\beta$-LG were removed in the $\mathrm{pH}$ range of 5.7 to 6.5 (results not shown).

The effect of the addition of different amount of chitosan on the removal of $\beta$-LG from whey at $\mathrm{pH} 6.2$ was investigated by RP-HPLC analysis of supernatants. Addition of $1.9 \mathrm{mg}$ of chitosan/mL gave rise to selective removal of $\beta-\mathrm{LG}$ as shown in Figure 2. The content of $\beta$-LG in solution decreased as the amount of chitosan added increased (Figure 3). Thus, addition from 1.9 to $3.0 \mathrm{mg}$ of chitosan/mL led to substantially complete removal of $\beta$-LG, whereas at least $80 \%$ of the rest of the whey proteins remained in solution. Treatment with 3.5 $\mathrm{mg}$ of chitosan $/ \mathrm{mL}$ gave rise to a slight decrease of BSA, $\alpha$-LA, and IgG contents in the whey supernatants. However, increasing the chitosan concentration to 4 $\mathrm{mg} / \mathrm{mL}$ resulted in partial restabilization of the coagulated proteins. This is a typical phenomenon due to overdosing with organic polymers as previously described (O'Melia, 1972; Bough and Landes, 1976; Moore et al., 1987; Kennedy et al., 1992; Jun et al., 1994; Casal et al., 2005).

Caseins and $\beta$-LG are the major allergens described in cow's milk (Host and Halken, 1990; Bush and Hefle,
1996), which places significant restrictions on the use of WPC as a food ingredient. The allergenicity of WPC could be significantly reduced by first removing $\beta$-LG, which would help to broaden the applications for WPC in the food industry.

On the other hand, because human milk contains negligible quantities of $\beta$-LG, the obtainment of $\beta$-LGfree whey would find immediate application as the primary protein constituent of hypoallergenic infant formulas with protein compositions that are more similar to that of human milk (Heine et al., 1991; Pearce, 1991). An additional advantage would be the presence of $\mathrm{IgG}$, because it is considered one of the most important factors in resistance to infections. Indeed, the transfer of maternal IgG during pregnancy through the human placenta and via lactation provides the newborn with passive immunity to a number of infectious agents (Kristoffersen and Matre, 1996).

Chitosan is a derivative of chitin, which is one of the most abundant natural amino polysaccharides extracted from a wide range of natural sources such as crustaceans, insects, and fungi (Shepherd et al., 1997). Thus, the easy accessibility and low cost of chitosan (Hwang and Damodaran, 1995) makes the process to selectively remove $\beta$-LG from cheese whey industrially feasible.

In conclusion, this work shows the feasibility of using chitosan to selectively reduce $\beta$-LG present in whey. Moreover, the procedure allows the isolation of undenatured $\beta$-LG that could be utilized in a number of food applications.

\section{ACKNOWLEDGMENTS}

This work was supported by the Comisión Interministerial de Ciencia y Tecnología (CICYT), Project number AGL2004-07227-C02-02.

\section{REFERENCES}

Alomirah, H. F., and I. Alli. 2004. Separation and characterization of $\beta$-lactoglobulin and $\alpha$-lactalbumin from whey and whey protein preparations. Int. Dairy J. 14:411-419.

Armstrong, J. M., K. E. Hopper, H. A. McKenzie, and W. H. Murphy. 1970. On the column chromatography of bovine whey proteins. Biochim. Biophys. Acta 214:419-426.

Ausar, S. F., I. D. Blanco, R. G. Badini, L. F. Castagna, N. M. Modesti, C. A. Landa, and D. M. Beltrano. 2001. Characterization of casein micelle precipitation by chitosans. J. Dairy Sci. 84:361-369.

Bough, W. A., and D. R. Landes. 1976. Recovery and nutritional evaluation of proteinaceous solids separated from whey by coagulation with chitosan. J. Dairy Sci. 59:1874-1880.

Bramaud, C., P. Aimar, and G. Daufin. 1997. Whey protein fractionation: Isoelectric precipitation of $\alpha$-lactalbumin under gentle heat treatment. Biotechnol. Bioeng. 56:391-397.

Bush, R. K., and S. L. Hefle. 1996. Food allergens. Crit. Rev. Food Sci. Nutr. 36:S119-S163.

Casal, E., N. Corzo, F. J. Moreno, and A. Olano. 2005. Selective recovery of glycosylated caseinmacropeptide with chitosan. J. Agric. Food Chem. 53:1201-1204. 
Chavasit, V., C. Kienzle Sterzer, and J. A. Torres. 1988. Formation and characterization of an insoluble polyelectrolyte complex: Chitosan-polyacrylic acid. Polym. Bull. 19:223-230.

Cheang, B., and A. L. Zydney. 2003. Separation of $\alpha$-lactalbumin and $\beta$-lactoglobulin using membrane ultrafiltration. Biotechnol. Bioeng. 83:201-209.

De Vries, R. 2004. Monte Carlo simulations of flexible polyanions complexing with whey proteins at their isoelectric point. J. Chem. Phys. 120:3475-3481.

Der Chyan, H., and D. Srinivasan. 1995. Selective precipitation and removal of lipids from cheese whey using chitosan. J. Agric. Food Chem. 43:33-37.

Felipe, X., and A. J. Law. 1997. Preparative-scale fractionation of bovine, caprine and ovine whey proteins by gel permeation chromatography. J. Dairy Res. 64:459-464.

Fernández, M., and P. F. Fox. 1997. Fractionation of cheese nitrogen using chitosan. Food Chem. 58:319-322.

Gurgel, P. V., R. G. Carbonell, and H. E. Swaisgood. 2000. Fractionation of whey proteins with a hexapeptide ligand affinity resin. Bioseparation 9:385-392.

Guzey, D., and D. J. McClements. 2006. Characterization of $\beta$-lactoglobulin-chitosan interactions in aqueous solutions: A calorimetry, light scattering, electrophoretic mobility and solubility study. Food Hydrocoll. 20:124-131.

Haeusel, R., P. C. Lorenzen, E. H. Reimerdes, and H. Brueckner. 1990. Fractionation of main whey proteins and potential industrial feasibility. II. Eur. Dairy Mag. 2:4.

Heine, W. E., P. D. Klein, and P. J. Reeds. 1991. The importance of alpha-lactalbumin in infant nutrition. J. Nutr. 121:277-283.

Hidalgo, J., and P. M. T. Hansen. 1971. Selective precipitation of whey proteins with carboxymethylcellulose. J. Dairy Sci. 54:1270-1274.

Host, A., and S. Halken. 1990. A prospective study of cow milk allergy in Danish infants during the first 3 years of life. Allergy $45: 587-596$

Hwang, D.-C., and S. Damodaran. 1995. Selective precipitation and removal of lipids from cheese whey using chitosan. J. Agric. Food Chem. 43:33-37.

Jun, H. K., J. S. Kim, H. K. No, and S. P. Meyers. 1994. Chitosan as a coagulant for recovery proteinaceous solids from tofu wastewater. J. Agric. Food Chem. 42:1834-1838.

Kennedy, J. F., M. Paterson, and M. P. C. Silva. 1992. Recovery of proteins from whey using chitosan as coagulant. Abstr. Pap. Am. Chem. Soc. 203:78-PMSE, Part 3. Apr 5:150-151.

Kinekawa, Y., and N. Kitabatake. 1996. Purification of beta-lactoglobulin from whey protein concentrate by pepsin treatment. J. Dairy Sci. 79:350-356.
Knorr, D. 1991. Recovery and utilization of chitin and chitosan in food processing waste management. Food Technol. 45:114-122.

Kristoffersen, E. K., and R. Matre. 1996. Co-localization of the neonatal Fc gamma receptor and IgG in human placental term syncytiotrophoblasts. Eur. J. Immunol. 26:1668-1671.

Leman, J., and T. Dolgan. 2001. Whey protein fractionation. Przem. Spozywczy 55:41-45.

Mailliart, P., and B. Ribadeau-Dumas. 1988. Preparation of $\beta$-lactoglobulin and $\alpha$-lactoglobulin-free proteins from whey retentate by sodium chloride salting out at low pH. J. Food Sci. 53:743-745.

Moore, K. J., M. G. Johnson, and W. A. Sistrunk. 1987. Effect of polyelectrolyte treatments on waste strength of snap and dry bean wastewater. J. Food Sci. 52:491-492.

Mukhopadhyay, R., D. Talukdar, B. P. Chatterjee, and A. K. Guha. 2003. Whey processing with chitosan an isolation of lactose. Process Biochem. 39:381-385.

Muzzarelli, R. A. A., C. Muzzarelli, and M. Terbojevich. 1997. Chitosan chemistry, upgrading a renewable source. Carbohydr. Eur. 19:10-17.

Neall, B. 2002. The wonderful ways of whey. Food Rev. 29:17-19.

O'Melia, C. R. 1972. Coagulation and flocculation. Pages 61-110 in Physicochemical Processes for Water Quality Control. W. J. Weber Jr., ed. Wiley-Interscience, New York, NY.

Outinen, M., O. Tossavainen, T. Tupasela, P. Koskela, H. Koskinen, P. Rantamaki, E. L. Syvaoja, P. Antila, and V. Kankare. 1996. Fractionation of proteins from whey with different pilot scale processes. Lebensm. Wiss. Technol. 29:411-417.

Pearce, R. J. 1991. Applications for cheese whey protein fractions. Food Res. Quart. 51:74-85.

Schnack, U., E. H. Reimerdes, and H. Klostermeyer. 1978. Isolation of alpha-lactalbumin from milk on a semi-technical scale. Kieler Milchw. Forsch. 30:351-359.

Selmer Olsen, E., H. C. Ratnaweera, and R. Pehrson. 1996. A novel treatment process for dairy wastewater with chitosan produced from shrimp-shell waste. Water Sci. Technol. 34:33-40.

Shepherd, R., S. Reader, and A. Falshaw. 1997. Chitosan functional properties. Glycoconj. J. 14:535-542.

Sienkiewicz, T. 1975. Investigation of ultrafiltrated whey proteins by gel chromatography and electrophoresis. Nahrung 19:143-154.

Zayas, J. F. 1997. Foaming properties of proteins; Gelling properties of proteins. Pages 260-366 in Functionality of Proteins in Food. Ed: Springer-Verlag. Berlin, Germany.

Zydney, A. L. 1998. Protein separation using membrane filtration: New opportunities for whey fractionation. Int. Dairy J. 8:243-250. 